\title{
Laboratory Remediation of Iron-Sulphate Contaminant in Acid Mine Waters Using Waste Rocks
}

\author{
Saheed Oke ${ }^{1}$, Megan Purchase ${ }^{2}$, Lerato Mokitlane ${ }^{3}$ \\ ${ }^{1}$ Unit for Sustainable Water and Environment, Civil Engineering Department, Central University of Technology \\ Parkwest, Bloemfontein, South Africa \\ soke@cut.ac.za; purchased@ufs.ac.za \\ ${ }^{2}$ Department of Geology, University of Free State \\ Brandwag, Bloemfontein, South Africa \\ L.Mokitllane@gmail.com \\ ${ }^{3}$ Council for Geosciences, \\ Silverton, Pretoria, South Africa
}

\begin{abstract}
In this paper, laboratory techniques of removing acid mine drainage rich in iron and sulphate is highlighted. AMD are contaminated water generated from mining of metals rich ore bodies such as pyrites and other iron and sulphide rich minerals. Three waste rocks of shale, bentonite and a mixture rock (shale-bentonite-calcrete) were used in removing the iron-sulphate concentration. Physico-chemical remediating process was carried out in the laboratory targeting the removal of the iron and sulphate in the AMD using these waste rocks. The remediation involved grinding the waste rocks into different particle sizes and sorting the grains using ASTM standard. The sorted waste rocks were arranged into three transparent bottle with regulated dip end. Each waste rock was placed into a distinct bottle. AMD rich in iron-sulphate was sourced from an abandoned mine. The iron-sulphate concentration in the AMD was determined using ICP-MS. The iron-sulphate concentration was determined before and after the remediation. Result show iron concentration in the AMD was $253 \mathrm{mg} / \mathrm{l}$ before remediation and $0.08 \mathrm{mg} / 1,0.02 \mathrm{mg} / \mathrm{l}, 0.80 \mathrm{mg} / \mathrm{l}$ after remediation for bentonite, mixture and shale respectively. Likewise, sulphate concentration before remediation was $5067 \mathrm{mg} / \mathrm{l}$ before remediation and $3207 \mathrm{mg} / \mathrm{l}, 3662 \mathrm{mg} / \mathrm{l}$, $2238 \mathrm{mg} / \mathrm{l}$ after remediation for bentonite, mixture and shale respectively. The laboratory experimentation has shown that controlled laboratory techniques can be used in removal of iron and minimise sulphate contained in AMD. The use of waste rocks of shale or bentonite with variety of grain size contents will remove iron-sulphate contamination and if use as liners in a constructed wetland will minimise the generation of AMD.
\end{abstract}

Keywords: Shale, Bentonite, AMD, Iron-Sulphate, Remediation.

\section{Introduction}

Acid Mine Drainage (AMD) is flow of water out of a mine that has a very high acidic content after it has been in contact with air and metals. Iron and sulphate are the major metals found in AMD. These metals result from oxidation of minerals inherent in these metals ore bodies and surrounding rocks. Major minerals forming AMD are chalcopyrite $(\mathrm{CuFeS})$, molybdenite $(\mathrm{MoS} 2)$, galena $(\mathrm{PbS})$, pyrite $\left(\mathrm{FeS}_{2}\right)$ and Pyrrhotine $(\mathrm{FeS})$. In the presence of oxygen and water, pyrite oxidizes to form $\mathrm{Fe}^{2+}, \mathrm{SO}_{4}{ }^{2+}$ and $\mathrm{H}^{+}$ions $[1,2]$.

$$
2 \mathrm{FeS}_{2(\mathrm{~s})}+70_{2(\mathrm{~g})}+2 \mathrm{H}_{2} \mathrm{O}_{(\mathrm{l})}=2 \mathrm{Fe}^{2+}{ }_{(\mathrm{aq})}+4 \mathrm{SO}_{4}{ }^{2-}(\mathrm{aq})+4 \mathrm{H}^{+}{ }_{(\mathrm{aq})}
$$

The formation of sulphuric acid decreases the $\mathrm{pH}$ of the water. This lead to complete oxidation of pyrite to ferric iron and precipitation of ferric hydroxide termed yellow boy [3,4].

AMD generation release high concentrations of heavy metals into the environment causing environmental concerns. Water bodies (groundwater and surface water) are contaminated chiefly by iron and sulphate from the AMD [5, 6]. AMD are major cause of point source pollutions in adjoining water bodies it is generated. AMD affect aquatic life and stimulate generation of other metals. The high iron and sulphate content in AMD lowers water quality which makes natural water unfit for intended purposes. 
Few studies carried out on remediating AMD include passive and active technologies [7]. AMD remediation has been carried out in numerous laboratory studies $(8,9]$. Gitari et al. [9] and Basir and Yaacob et al. [10] had practicalised in the laboratory the usefulness of bentonite in AMD remediation. Oke and Vermeulen [11] suggested the use of site specific remediation techniques to combat pollutant from mining sites. Luptakova et al. [12] attempted removal of sulphate from AMD using sulphate removal bacteria (SRB). The target of iron removal in most water treatment process is precipitation. Therefore, this paper presents the results of a laboratory removal of iron and sulphate from AMD by using three waste rocks materials.

\section{Methodology}

A detailed processes carried out in the laboratory for the remediation of iron and sulphate in the acid mine water is shown in the bullet below. The description is highlighted in such a manner for ease of replica either in the field at the site of AMD generation or in another laboratory.

\subsection{Procedure for Laboratory Sample Preparation and Remediation}

- Acid mine water was sourced from an abandoned mine. The mine was for coal production which are characterised for producing high concentration of pyrite oxidation.

- Acid mine water sampling followed the standard procedures for surface water sampling. Sample bottles was sterile before rinsing with the contaminated flowing mine water at the point of sampling.

- Waste rock from an active bentonite mine was sourced. The samples collected include rocks with larger percentage of pure bentonite, a mixture of shale, bentonite and calcrete and a pure shale rock types.

- $5 \mathrm{~kg}$ of each rock types were grinded into different particles sizes. The range of the particles sizes are $>700 \mu \mathrm{m}, 300$ $710 \mu \mathrm{m}, 150-300 \mu \mathrm{m}, 75-150 \mu \mathrm{m}, 38-75 \mu \mathrm{m}$ and $<38 \mu \mathrm{m}$.

- The grainsizes sorting was done through a sieve shaker and ASTM sieve sizes.

- 1 litre plastic bottle with a controlled tip was sterile and cut at one end to allow gentle placement of grinded waste rock.

- The grinded waste rock sizes are aggregated into the sterilised plastic bottle.

- Amount of each grain of waste rocks filled into the bottles is shown in figure 1.

- Filter paper was placed between the particle sizes in each plastic bottle. This is to allow measuring the effectiveness of each filter layer.

- Acid mine water was analysed for metals concentrations before the experimentation using ICP-MS at the water laboratory of Institute for Groundwater Studies of University of Free State. This result serves as the control sample

- After the experiments, the filtered water was analysed at the same water laboratory for the three samples. These was compared to the control sample to detect the effectiveness and ability of the three waste rock sample to reduce the iron and sulphate concentrations in the water.
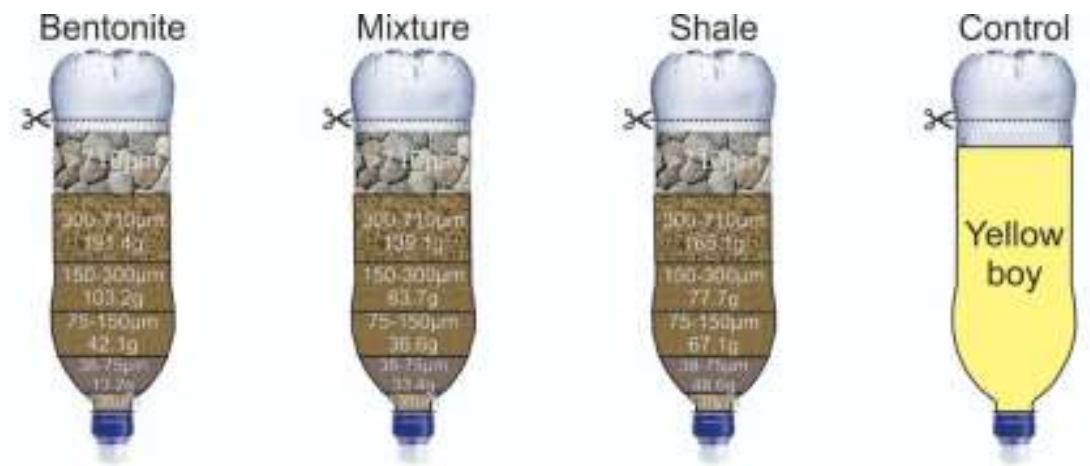

Fig. 1: Description of laboratory remediation of AMD water in the column of three waste rocks. 


\section{Result}

Table 1 shows the grain particles and weight of waste rocks of each layer used in the remediation. The particle sizes range from coarse sand $(>710 \mu \mathrm{m})$ to medium sand $(710-300 \mu \mathrm{m})$ to fine sand $(300-75 \mu \mathrm{m})$ to silt $(75-38 \mu \mathrm{m})$ and clay $(<15$ $\mu \mathrm{m})$. Clay and silt present the lowest grain weight with bentonite clay and silt grain weight, the lowest in the three sample. Elemental concentrations of AMD before remediation shows major contamination of iron and sulphate in the water. After, remediation, the iron was totally removed in the water from the three waste rocks while sulphate concentration was reduced. Shales waste rock performed best at removing the sulphate (Table 2). This may be due to shale having larger percentage weight of clay and silt fraction than bentonite and mixture. The laboratory experimentation was based on both physical and chemical techniques of remediation. Filtration of waste water through the particle layer is the physical process of remediation used in the study while ion exchange was the chemical remediating process. The filtration processes allow for the removal of solute (precipitate) in water. Yellow boy precipitate from mine water was trapped unto the layers of the waste rocks in each column.

Table 1: Waste rock grain particle sizes and weight of grain content used for the remediation.

\begin{tabular}{|l|l|l|l|}
\hline Grainsizes & Bentonite $(\mathrm{g})$ & Mixture $(\mathrm{g})$ & Shale $(\mathrm{g})$ \\
\hline$>710 \mu \mathrm{m}$ & 250 & 245 & 285 \\
\hline $710-300 \mu \mathrm{m}$ & 191.4 & 139.1 & 165.1 \\
\hline $300-150 \mu \mathrm{m}$ & 103.2 & 63.7 & 77.7 \\
\hline $150-75 \mu \mathrm{m}$ & 42.1 & 36.6 & 67.1 \\
\hline $75-38 \mu \mathrm{m}$ & 13.2 & 33.4 & 48.6 \\
\hline$<38 \mu \mathrm{m}$ & 15 & 18 & 18 \\
\hline
\end{tabular}

The cation exchange of iron and sulphate elements in pyrites with elemental compositions of the waste rock is the target of the chemical treatment. Here, major cations such as sodium, magnesium and calcium in the waste rocks react with the sulphate of the mine water to form other compounds by displacing the iron. The iron is displaced in the water and retained within the waste rock (Fig. 1). Manganese, is as well displaced in the waste rock remediated water. The mixture removed completely the manganese present in the water below the WHO drinking water standard [13] (Table 2). Shale performed better in reducing the concentration of sulphate because unlike bentonite and the mixture, sulphate rich AMD lack adequate electrons [12] which the shale waste rocks has considerate amount in its mineralogical composition to donate.

Sulphate present in the water above $400 \mathrm{mg} / \mathrm{l}$ is not considered toxic but will negatively affect the taste of water which results in laxative effect [12]. However, sulphide developed from anoxic condition from sulphate can cause death to aquatic life due to reduced oxygen. It is necessary to note the importance of resident time of AMD passing through the layers of waste rocks. It is observed from the laboratory experimentation that for an effective remediation and complete ion exchange of either the sulphate or iron, the pore spaces of waste rock to be used mustn't allow rapid discharge of AMD water. The infiltration rate must be slow enough to permit for the interaction of the waste rock materials and the AMD. The more the resident time of AMD water in the water column, the better the effectiveness of its remediation.

Table 2: Iron and Sulphate concentration before and after treatment with the three waste rocks materials. All values are in $\mathrm{Mg} / \mathrm{L}$.

\begin{tabular}{|l|l|l|l|l|l|}
\hline Determinant & AMD & Bentonite & Mixture & Shale & WHO (2016) \\
\hline Iron & 253.2 & 0.080 & $<0.020$ & $<0.080$ & 0.3 \\
\hline Sulphate & 5067 & 3207 & 3662 & 2238 & 400 \\
\hline Manganese & 58.07 & 3.28 & 0.10 & 2.48 & 0.5 \\
\hline
\end{tabular}

\section{Conclusion}

The laboratory experimentation has shown that control strategy can be used in minimising the formation of AMD. The use of waste rocks of shale or bentonite with variety of grain size contents as liners in a constructed wetland will minimise the generation of AMD. The major advantages of laboratory experimentation of AMD remediation are that it can be carried 
out at the base of rocks or points where AMD is formed or along the flow path of AMD water. Using these methods, it becomes cheaper and easier to remediate iron-sulphate contaminations in AMD at or near the source of generation.

\section{Acknowledgements}

The researchers would like to acknowledgement the Institute for Groundwater Studies of University of Free State for sponsoring the third authors studies. The Central University of Technology Free State for supporting the first author to present the paper. Special thanks to Council for Geoscience, Pretoria for providing the Acid Mine Water used for the research.

\section{References}

[1] W. Stumm and J. J. Morgan, Aquatic chemistry: an introduction emphasizing chemical equilibria in natural waters. 2nd ed. New York: Wiley; 1981.

[2] A. RoyChowdhury, D. Sarkar and R. Datta, Curr Pollution Rep. vol. 1, pp. 131, 2015.

[3] C. Costello, Acid Mine Drainage: Innovative Treatment Technologies. National Network of Environmental Management Studies, Washington DC, 2003.

[4] M. F. van den Berg, M. Botes, E. Slabber and T. E. Cloete, "Evaluating sulphate removal and identifying the bacterial community present in acid mine drainage treated with synthetic domestic wastewater sludge," Water SA, vol. 42, no. 3, 2016.

[5] P. J. Hobbs and J. E. Cobbing, "A Hydrogeological Assessment of Acid Mine Drainage Impacts in the West Rand Basin,” Gauteng Province. Report no, CSIR/NRE/WR/ER/2007/0097/C. CSIR/THRIP. Pretoria. South Africa, 2007.

[6] INAP - International Network for Acid Prevention, Treatment of Sulphate in Mine Effluents, LORAX Environmental, Inc 129, 2003.

[7] D. B. Johnson and K. B. Hallberg, "Acid mine drainage remediation options: a review," Sci. Total Environ, vol. 338, pp. 3-14, 2005.

[8] D. J. Soucek, D. S. Cherry, R. J.Currie, H. A. Latimer and G. C. Trent, "Laboratory and field validation in an integrative assessment of an acid mine drainage-impacted watershed," Environ Toxicol Chem., vol. 19, no. 4, pp. 1036-43, 2000.

[9] W. M. Gitari, C. Kaseke and B. B. Nkuzani, "Passive Remediation of Acid Mine Drainage using Bentonite Clay: A Laboratory Batch Experimental Study," Mine Water-Managing the Challenges, Aachen Germany, 2011.

[10] N. A. M. Basir and W. Z. Yaacob, "Remediation of AMD using natural and waste material," AIP Conf. Proc. 1614, pp. 808-814, United States, 2014.

[11] S. Oke and D. Vermeulen, "Geochemical Modeling and Remediation of Heavy Metals and Trace Elements from Artisanal Mines Discharge," Soil and Sediment Contamination: An International Journal, vol. 26, no. 1, pp. 84-95, 2017.

[12] A. Luptáková, E. Mačingová, I. Kotuličová and D. Rudzanová, "Sulphates Removal from Acid Mine Drainage IOP," Conf. Series: Earth and Environmental Science, vol. 44, pp. 052040, 2016.

[13] World Health Organization (WHO), Guidelines for drinking water quality. Final Task Group Meeting, Geneva, 2016. 